\title{
Secular Changes in Male Body Height in the European Part of Russia during the 20th Century
}

\author{
Lidia Lebedeva1, Yulia Kucherova² and Elena Godina ${ }^{3}$ \\ ${ }^{1}$ Public Opinion Foundation, Moscow, Russia \\ ${ }^{2}$ Yamal LNG, Moscow, Russia \\ ${ }^{3}$ Institute and Museum of Anthropology, Lomonosov Moscow State University, Moscow, Russia
}

\begin{abstract}
A B S T R A C T
Significant political and economic transformations took place on the territory of contemporary Russia in the first part of the 20th century. We hypothesized that they would have affected male growth curve negatively. To test this idea, the dataset was collected to present the graph, which illustrates the changes in male body height during the 20th century. We searched for bibliographic sources with information about body height of men and women born during the 20th century, with full description of measurement methodology, sample design and significant geographical distribution of the dataset covering more than 15 territories of the country - cities or regions. Such criteria were met only for men. We found only 8 sources that could be considered reliable in the research. The observed graph confirms positive changes in male body height on the territory of the European part of contemporary Russia: for those, who were born in 1900's it was $166.1 \mathrm{~cm}$, in $1920 \mathrm{~s}-166.5 \mathrm{~cm}$, in $1940 \mathrm{~s}-171 \mathrm{~cm}$, in $1960 \mathrm{~s}-174.8 \mathrm{~cm}$ and in $1980 \mathrm{~s}$ the indicator reached $176.1 \mathrm{~cm}$. No significant negative changes in this indicator have been found during the studied period. The primary hypothesis that political and socio-economic transformations affect male growth curve negatively was confirmed only partly. We concluded that unfavorable political and socio-economic events (such as revolutions, World War I and World War II, purges and famines) influenced the pace of body height increase in men. While the main period of secular trend was fixed in the first decades of the 20th century in Germany, Netherlands and France, in this part of Russia it occurred later, in 1930-1960s. However, the total increase in male height was very similar for all mentioned territories (9-11 cm) during 1900-1980's.
\end{abstract}

Key words: anthropology, height, men, Russia, 20th century, continuous curve of secular changes

\section{Introduction}

A lot of political and socio-economic transformations, such as revolutions, World War I and World War II, purges and famines tormented the territory of contemporary Russian Federation in the first part of the 20th century. Total population loss during the World War II is widely-known and it equals 26.6 millions of people (15.6\% of population before the war at 1939)a. In the 1920-1940's the evaluations of victims of political repressions differ from 4.06 to 6.98 millions of people ${ }^{b}$. At the same time about 10 millions of people departed from the place of their birth ${ }^{c}$. Moreover, the severe famines in 1921-1922, 1932-1933 and 1946-

\footnotetext{
ahttps://ru.wikipedia.org/wiki/Потери_во_Второй_мировой_войне bhttps://www.politpros.com/journal/read/?ID=783

https://www.memo.ru/media/uploads/2017/08/22/masshtabysovetskogo-politicheskogo-terrora.pdf

chttp://www.demoscope.ru/weekly/2007/0313/analit04.php
}

1947 caused deaths of approximately 5.3 and 1.5 millions ${ }^{\mathrm{d}}$. We could only imagine the number of people, who suffered from malnutrition and starvation during all mentioned events. The point of discussion is whether these miseries and losses in Russia in the first part of the $20^{\text {th }}$ century affected the body height of the population.

Firstly, we need to understand in what ways body height changes. This question seems to be easy, if there are official published datasets available. Unfortunately, after the year 1927 anthropometric measurements of conscripts in the USSR became a military secret ${ }^{1}$. No officially published statistical information is available for

\footnotetext{
dhttps://ru.wikipedia.org/wiki/Голод_в_Поволжье_

(1921-1922)\#Масштаб_и_последствия_голода; https://ru.

wikipedia.org/wiki/Голод_в_CCCP_(1946-1947); https://ru.

wikipedia.org/wiki/Голод_в_CССР_(1932-1933)
} 
adults born after 1909. This kind of information is not aggregated by the statistical committee in contemporary Russia. As a result, some researchers implement the procedure of modeling this indicator for the $20^{\text {th }}$ century in our country ${ }^{2}$. However, secular trends were convincingly proved in plenty scientific works for different Russian cities and regions based on the measurements of children and adolescents ${ }^{3-5}$. No research has been made yet concerning the changes of adult body height for the whole territory of Russia in the $20^{\text {th }}$ century. This is a rather complicated task, because ethnicity of the participants, place of living, geographical distribution of the research samples influenced body height and its differentiation on the territory of Russia.

In our study we will use mostly data on men's height. The reason for that is that there is lack of measurements of female height in the bibliographic sources. It is impossible to create a continuous line from the beginning of the century for women.

The main goal of the article is to illustrate the changes in male body height during the $20^{\text {th }}$ century. To do so we clarified the methodology for making this graph. On the assumption of the well-known Tanner's statement about the growth as a mirror of the condition of society, we hypothesized that political and social transformations that happened in Russia during the first half of the $20^{\text {th }}$ century could affect male growth curve negatively, because the society endured a lot of unfavorable social events and people were deeply involved into them physically and physiologically ${ }^{6}$.

\section{Materials and Methods}

\section{Sources of information}

To achieve our goal, we searched for all available sources of information. Data about body height of men who were born before 1960 were found in the library of the Anuchin Research Institute and Museum of Anthropology, Lomonosov Moscow State University. Criteria for research were defined. We were interested in bibliographic sources with information about body height of men and women born in the $20^{\text {th }}$ century, with full description of methodology of measurement and sample design. Moreover, geographical distribution of the dataset had to be significant (covering more than 15 territories - cities or regions). These criteria were met only in 6 sources $^{7-12}$ and contained information only about men's body height (Table 1).

Sources of the information about body height of men and women born after the year 1970 which would meet above criteria were not found in the library. Hence, we analyzed several datasets that had body height indicators and information about sex, year and place of birth and place of residence. A dataset from Health Centers was provided by the team of scientistse. Unfortunately, in this

eded by V.I. Starodubov at the Central Scientific Research Institute for Hygiene of the Russian Ministry of Health with the support of the Russian Science Foundation (grant No. 14-15-01085). dataset ethnicity of the participants was not recorded. Due to this fact the value of standard deviation is higher than in the other samples ${ }^{13}$.

Another dataset that contains all necessary information about body height and personal characteristics was Russian Longitudinal Monitoring Survey made by a research group at the Higher School of Economics (RLMS HSE). This dataset also contains information about ethnicity of the participants. We used the methodology of aggregation of self-reported data on body height in order to use information only from those participants who knew their exact body height. We used information about personal height of the participant only if one was involved in the survey twice or more times during 1994-2016 and specified one's height with precision of $1 \mathrm{~cm}$.

Taking into account geographical distribution of the survey samples we have found suitable datasets before 1960 (Table 1$)^{7-11}$, that were collected in the regions and cities situated in the European part of Russia. Information from this dataset forms a significant part of all analyzed information. Thus, all other datasets were recalculated according to geographical position of the sample. The decision was made to create a graph only for the European part of contemporary Russia with some exceptions. We included in our analyses the information about Ekaterinburg and Kurgan, which are normally considered as a part of non-European territory of Russia.

Full description of the survey samples, age and years of birth of the participants, as well as information about ethnicity are provided in Table 1. Geographical distribution of the places where samples were collected is shown on the maps (Figures 1a-c).

Data presented in the table are based on the abovementioned criteria. In a whole, we analyzed and compared datasets with the body height measurements of young or middle-aged men, after the completion of their growth process (exception row 6 in Table 1). The height limitation was canceled in the 1917. Thus, samples consisted of recruits, who were measured in 1927, and could be compared to other samples that included non-recruits. Every sample has a sufficient number of cases. The only dataset without the information on the number of measured individuals was published by V. Bunak in 1932 with the reference to officially printed statistical materials with data for all regions ${ }^{7}$. However, standard deviation value indicates that the size of this sample was rather significant.

According to Bunak's methodology body height remained stable till the age of 55 for men ${ }^{14}$. Contemporary studies have shown that changes in body height could be observed after the age of $35^{15}$. In our survey there were only two sources, where the middle-aged men's data were used. In the Bunak's work the height values were given for the exact age group (25-49 years old $)^{8}$. Thus, we used it as it was given by the author. Other authors (row 3 in Table 1) provided the information of the sample through the age of the participants. Due to this, it was possible to recalculate the data for the birth decades. 
TABLE 1

THE SOURCES OF INFORMATION FOR FIGURE 2 AND THEIR DESCRIPTION

\begin{tabular}{|c|c|c|c|c|c|c|c|c|c|}
\hline & The source of the dataset & $\begin{array}{l}\text { Year of the } \\
\text { survey }\end{array}$ & $\begin{array}{l}\text { Participants' } \\
\text { category }\end{array}$ & $\begin{array}{l}\text { Sample size by } \\
\text { geographical } \\
\text { distribution of } \\
\text { used data }\end{array}$ & $\mathrm{SD}$ & $\begin{array}{c}\text { Age of the } \\
\text { participants }\end{array}$ & $\begin{array}{l}\text { Approximate } \\
\text { years of birth }\end{array}$ & $\begin{array}{l}\text { Rural, } \\
\text { urban, } \\
\text { or both }\end{array}$ & Ethnicity \\
\hline 1 & $\begin{array}{l}\text { Bunak V.V. About the } \\
\text { changes in the growth } \\
\text { of the male population } \\
\text { in } 50 \text { years. }{ }^{7}\end{array}$ & 1927 & Recruits & $\mathrm{NA}$ & 3.7 & $18-22$ & 1906-1909 & Both & Russian \\
\hline 2 & $\begin{array}{l}\text { Bunak V.V. Origin and } \\
\text { ethnic history of the } \\
\text { Russian people (based on } \\
\text { anthropological data) }^{8}\end{array}$ & $1955-1959$ & Men & 5898 & 6.2 & $25-49$ & 1906-1934 & Both & Russian \\
\hline 3 & $\begin{array}{l}\text { Zenkevich P.I., Almazova } \\
\text { N.Y. About the change in } \\
\text { the size of the body of the } \\
\text { adult male population in } \\
\text { the Central part of Soviet } \\
\text { Union for the last } 100 \\
\text { years. }{ }^{9}\end{array}$ & $1974-1975$ & Men & 10931 & 5.8 & $18-56$ & $1919-1956$ & Urban & Russian \\
\hline 4 & $\begin{array}{l}\text { Purundzhan A.L. } \\
\text { Geographic variability of } \\
\text { anthropometric features } \\
\text { in Soviet Union. }{ }^{10}\end{array}$ & $1973-1974$ & Men & 1500 & 5.6 & $18-22$ & $1952-1956$ & Both & Russian \\
\hline 5 & $\begin{array}{l}\text { Deryabin V.Y., } \\
\text { Purundzhan A.L. About } \\
\text { the geographical features } \\
\text { of body composition in the } \\
\text { Soviet Union }{ }^{11}\end{array}$ & $1980-1981$ & Men & 2694 & NA & $18-20$ & $1960-1963$ & Both & Russian \\
\hline 6 & $\begin{array}{l}\text { Physical development of } \\
\text { children and adolescents } \\
\text { of urban and rural areas } \\
\text { in Soviet Union, IV (Pt. I } \\
\text { and II), } 1988^{12}\end{array}$ & $1971-1981$ & Adolescents & 5221 & 6.5 & 17 & $1954-1964$ & Both & Russian \\
\hline 7 & $\begin{array}{l}\text { Dataset from Health } \\
\text { centers }\end{array}$ & 2012 & Men & 16823 & 7.4 & $22-35$ & $1977-1990$ & Urban & NA \\
\hline 8 & $\begin{array}{l}\text { Aggregated dataset based } \\
\text { on RLMS HSE survey }\end{array}$ & $1994-2016$ & Men & 6163 & 6.2 & $22-35$ & 1961-1996 & Both & Russian \\
\hline
\end{tabular}

We suggested that the aggregated data recorded in 1988, row 6 in Table 1, where the age of investigated males was 17 years, might be below the true values, as the growth process in this group had not been finished at the moment of measurement ${ }^{12}$.

\section{Methods}

The graph (Figure 2) was constructed based on the data described above in the sources of information. On the graph, the data was provided by the years or decades of birth of the participants. Grey rectangles are illustrating the approximate period of birth of the participants (OX) and the value of the standard deviation coefficient (OY) for each dataset. Grey line is a median value of all used measurements of male body height.

\section{Results}

According to the line of the median value of male body height, positive changes in male body height could be observed in 1906 - 1996 birth decades. Thus, the indicator of body height for men born in $1900 \mathrm{~s}$ was $166.1 \mathrm{~cm}$, in $1920 \mathrm{~s}-166.5 \mathrm{~cm}$, in $1940 \mathrm{~s}-171 \mathrm{~cm}$, in $1960 \mathrm{~s}-174.8 \mathrm{~cm}$ and in $1980 \mathrm{~s}-176.1 \mathrm{~cm}$ (Figure 2).

The difference between RLMS HSE indicators (9) and source from 5 till 8 (points in the graph) could be explained by the data collecting methodology. In the RLMS HSE dataset indicators are based on self-reported values. Other sources contained real measurements. Despite of implemented verification procedure the differences in values are still obvious. The most significant difference is observed between RLMS HSE values of men's body height 


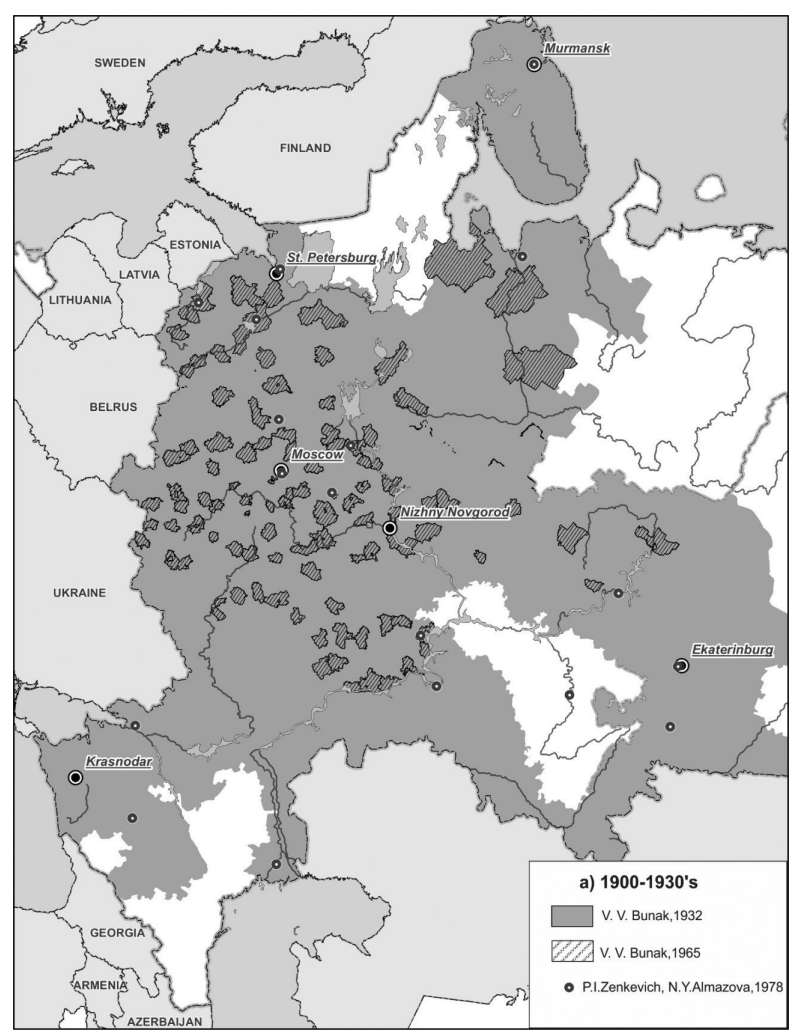

Fig. 1a. Geographical distribution of used datasets samples according to birth decades: 1900-1930's.

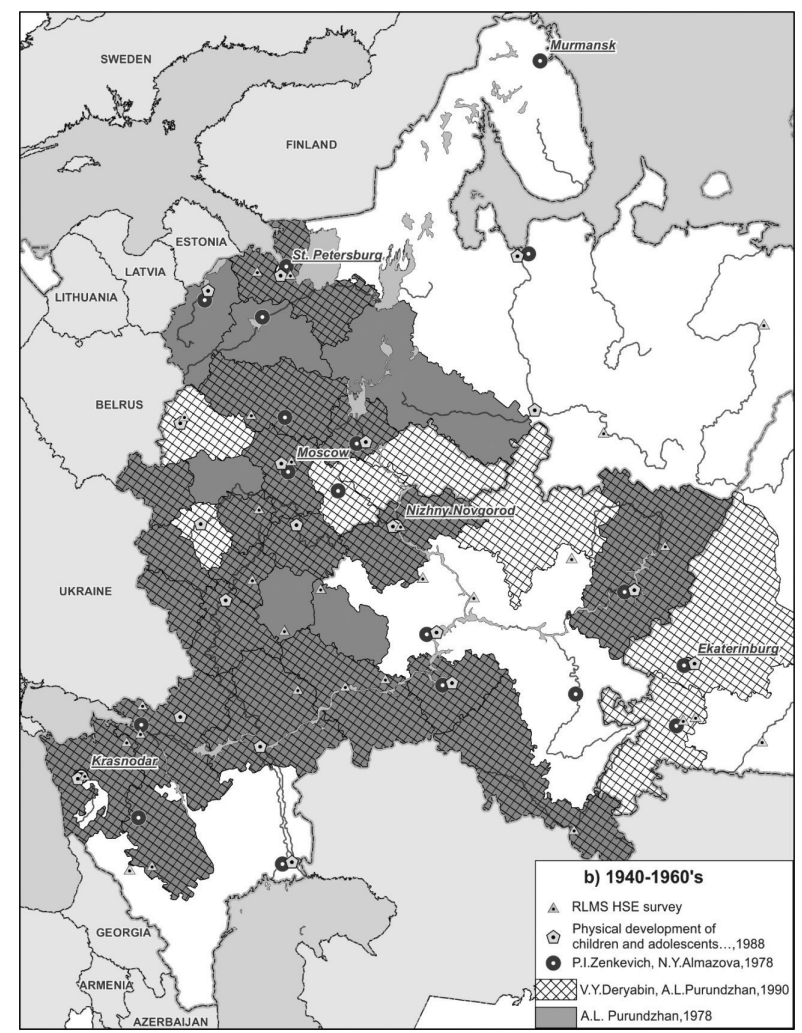

Fig. 1b. Geographical distribution of used datasets samples according to birth decades: 1940-1960's,

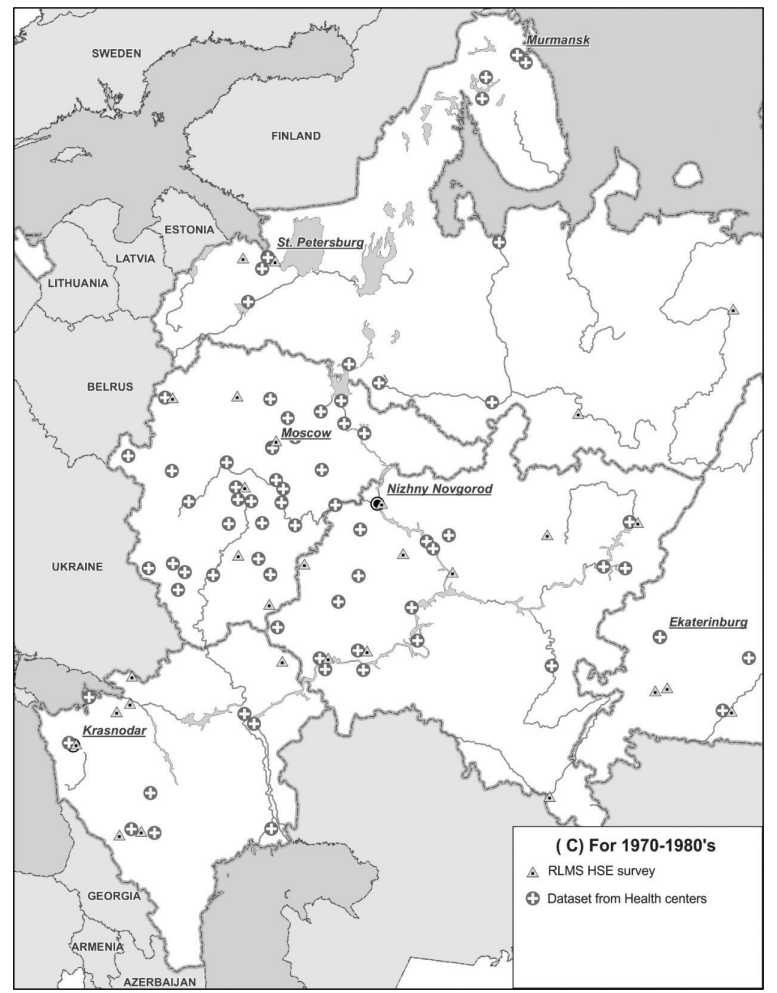

Fig. 1c. Geographical distribution of used datasets samples according to birth decades: 1970-1980's. 


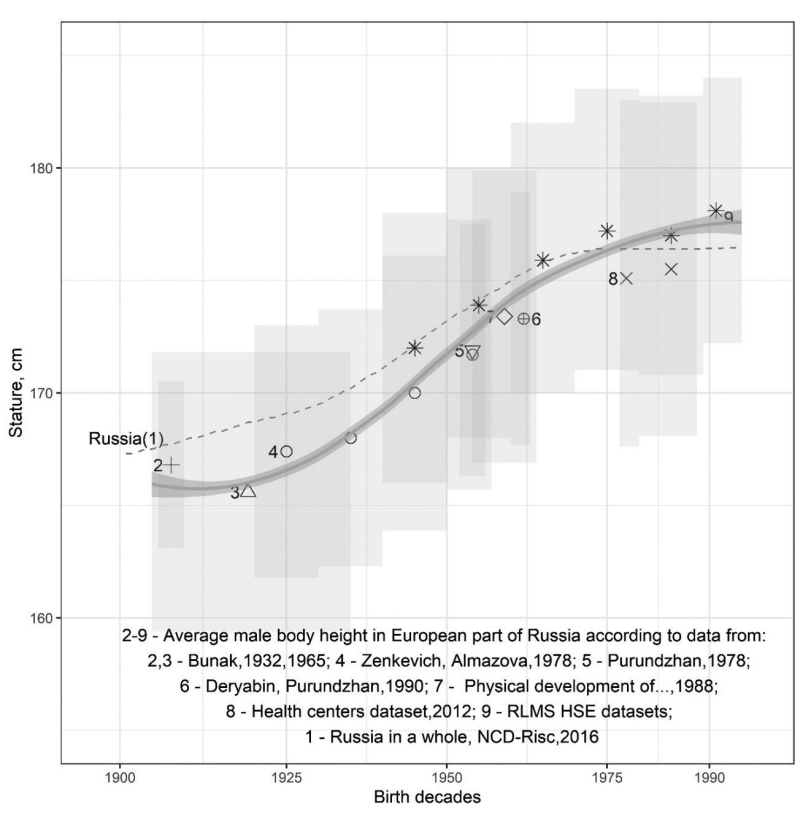

Fig. 2. Changes in male height on the territory of European part of Russia during the 20th century.

and values from health centers (up to $3 \mathrm{~cm}$ ). The differences in values might be due to the exclusion of the ethnicity factor during the process of measurement in one of the datasets. It was shown that the differentiation between the Slavic and non-Slavic ethnic groups, living in Russia, could be up to $2-3 \mathrm{~cm}^{16}$.

\section{Discussion}

According to Figure 2 and Table 2 positive changes are evident in male body height on the territory of the European part of contemporary Russia during the 20th century. No significant negative changes in this indictor have been found. This result is corresponding with the researches made in Germany, Italy, Sweden and Norway $^{17}$.

Most of the studies that showed negative consequences of unfavorable political or economic changes were based on longitudinal studies of people, who survived in these events and agreed to participate in follow-up observations, like in Netherlands after the Dutch hunger winter $^{18}$. Apparently, the absence of such available datasets in Russia influenced the observed results. Hermanussen and Scheffler basing on large sets of height data of European conscripts born between 1856-1860 and 1976-1980 explained the observed absence of negative trend in terms of strategic growth adjustment of the population to the unfavorable changes in the societies "that have increasingly been opened to upward social mobility and concomitant readjustments of target heights". Thus, social and political turmoil could facilitate upward mobility of the lower social strata, which could accompany by a general increase in height of the population in a whole ${ }^{19}$.

The line based on the dataset of NCD Risk Factor Collaboration differs from the provided median line ${ }^{20}$. Especially, the difference is evident for the first half of the $20^{\text {th }}$ century. This could be the result of the type of primary sources taken into account in the NCD RisC research. They are shown in the Table 3 . It is obvious that their evaluations were based on the resources, which could characterize the body height for men born after 1920 . We could suggest that during the period before 1920 data was evaluated with the extrapolation method. Thus, the graph presented in this research is more accurate for the territory and period in question. The difference between the values of body height indicators in our dataset and in NCD RisC after 1940s coincides nearly to $1 \mathrm{~cm}$.

Another significant dataset with the available values of male body height was published by Baten and Blum in the data hub "Heights and Biological Standard of Living" in $2012^{21}$. For Russia they took data mostly from the scientific publications presented in the list (Table 4). Their information also differs significantly from our evaluations till 1930s. Thus, Baten and Blum provided the value of male body height for those born in 1900s as 169.2 $\mathrm{cm}$ and duplicated it to those born in 1910s with the reference to the work of Jarcho ${ }^{22}$. Then, they used the value of $167,0 \mathrm{~cm}$ for those, who were born in $1920 \mathrm{~s}$ with the reference to Mironov ${ }^{23,24}$. Thus, confirming the idea that political events in the 1920s had a negative influence on body height.

However, according to Mironov the indicator of final body height of men born in Russian Empire was $167.4 \mathrm{~cm}$ for $1900 \mathrm{~s}^{1}$. According to Bunak's dataset the value was $166.8 \mathrm{~cm}$ for men born in 1906-1909. Unfortunately, there are no reliable sources of information about body height of young men, who were born in the 1910s, for the whole territory of Russia. The values in the Bunak's dataset that were printed in 1965, give the figure of 165.6 $\mathrm{cm}$ for men aged 25-49 born on the central plain of Russia. The indicator of male body height for those born in

TABLE 2

THE COMPARISON OF MALE BODY HEIGHT IN BIRTH DECADES IN DIFFERENT SOURCES OF INFORMATION FOR RUSSIA

\begin{tabular}{lccccccccc}
\hline Birth decades & 1900 's & 1910 's & 1920 's & 1930 's & 1940's & 1950's & 1960's & 1970 's & 1980 's \\
\hline Baten \& Blum .21 & 169.2 & 169.2 & 167.0 & 167.9 & 169.0 & 172.0 & 173.6 & 177.0 & 177.0 \\
NCD RiskC 20 & 167.6 & 168.3 & 169 & 170.2 & 172 & 174 & 175.7 & 176.4 & 176.4 \\
Median line, Figure 2. & 166.1 & 165.6 & 166.5 & 167.3 & 171 & 172.8 & 174.8 & 176.9 & 176.3 \\
\hline
\end{tabular}


TABLE 3

SOURCES OF INFORMATION FOR CONTEMPORARY RUSSIA IN NCD RISC DATASET FOR MEN20

\begin{tabular}{|c|c|c|c|c|c|}
\hline Data years & Survey/study name & $\begin{array}{l}\text { Level of } \\
\text { representativeness }\end{array}$ & Rural, urban, or both & $\begin{array}{l}\text { Age range as used } \\
\text { for global analysis }\end{array}$ & Sample size \\
\hline $1984-1986$ & $\begin{array}{l}\text { MONICA, Moscow (control) / Leninsky } \\
\text { district/ Cheremushkinsky district }\end{array}$ & Community & Urban & $35-64$ & $774 / 553 / 584$ \\
\hline 1985 & MONICA, Novosibirsk (intervention) & Community & Urban & $25-64$ & 797 \\
\hline 1986 & INTERSALT & Community & Urban & $20-59$ & 97 \\
\hline $1985-1986$ & $\begin{array}{l}\text { MONICA, Novosibirsk, Kirowsky district / } \\
\text { Leninsky district }\end{array}$ & Community & Urban & $25-64$ & $758 / 624$ \\
\hline 1988 & MONICA, Novosibirsk (intervention) & Community & Urban & $25-64$ & 837 \\
\hline $1988-1989$ & $\begin{array}{l}\text { MONICA, Moscow (control)/ Leninsky } \\
\text { district }\end{array}$ & Community & Urban & $35-64$ & $620 / 597$ \\
\hline $1988-1989$ & MONICA, Novosibirsk, Kirowsky district & Community & Urban & $25-64$ & 872 \\
\hline 1992-1995 & $\begin{array}{l}\text { MONICA, Moscow (control)/ Leninsky } \\
\text { district }\end{array}$ & Community & Urban & $35-64$ & $556 / 538$ \\
\hline $1992-1993$ & $\begin{array}{l}\text { Russia Longitudinal Monitoring Survey- } \\
\text { Higher School of Economics Round II }\end{array}$ & National & Both & $18+$ & 4381 \\
\hline 1993 & $\begin{array}{l}\text { Russia Longitudinal Monitoring Survey- } \\
\text { Higher School of Economics Round III }\end{array}$ & National & Both & $18+$ & 4556 \\
\hline $1993-1994$ & $\begin{array}{l}\text { Russia Longitudinal Monitoring Survey- } \\
\text { Higher School of Economics Round IV }\end{array}$ & National & Both & $18+$ & 4118 \\
\hline $1994-1995$ & MONICA, Novosibirsk (intervention) & Community & Urban & $25-64$ & 821 \\
\hline 1994 & $\begin{array}{l}\text { Russia Longitudinal Monitoring Survey- } \\
\text { Higher School of Economics Round V }\end{array}$ & National & Both & $18+$ & 3586 \\
\hline 1995 & MONICA, Novosibirsk, Kirowsky district & Community & Urban & $25-64$ & 771 \\
\hline 1995 & $\begin{array}{l}\text { Russia Longitudinal Monitoring Survey- } \\
\text { Higher School of Economics Round VI }\end{array}$ & National & Both & $18+$ & 3371 \\
\hline 1996 & $\begin{array}{l}\text { Russia Longitudinal Monitoring Survey- } \\
\text { Higher School of Economics Round VII }\end{array}$ & National & Both & $18+$ & 3323 \\
\hline 1998-1999 & $\begin{array}{l}\text { Russia Longitudinal Monitoring Survey- } \\
\text { Higher School of Economics Round VIII }\end{array}$ & National & Both & $18+$ & 3436 \\
\hline 2000 & $\begin{array}{l}\text { Russia Longitudinal Monitoring Survey- } \\
\text { Higher School of Economics Round IX }\end{array}$ & National & Both & $18+$ & 3523 \\
\hline 2001 & $\begin{array}{l}\text { Russia Longitudinal Monitoring Survey- } \\
\text { Higher School of Economics Round X }\end{array}$ & National & Both & $18+$ & 3884 \\
\hline 2002 & $\begin{array}{l}\text { Russia Longitudinal Monitoring Survey- } \\
\text { Higher School of Economics Round XI }\end{array}$ & National & Both & $18+$ & 4076 \\
\hline 2003 & $\begin{array}{l}\text { Russia Longitudinal Monitoring Survey- } \\
\text { Higher School of Economics Round XII }\end{array}$ & National & Both & $18+$ & 4137 \\
\hline $2002-2005$ & $\begin{array}{l}\text { Health, Alcohol and Psychosocial factors In } \\
\text { Eastern Europe }\end{array}$ & Community & Urban & $45-69$ & 4204 \\
\hline 2004 & $\begin{array}{l}\text { Russia Longitudinal Monitoring Survey- } \\
\text { Higher School of Economics Round XIII }\end{array}$ & National & Both & $18+$ & 4153 \\
\hline 2005 & $\begin{array}{l}\text { Russia Longitudinal Monitoring Survey- } \\
\text { Higher School of Economics Round XIV }\end{array}$ & National & Both & $18+$ & 4031 \\
\hline 2007-2010 & SAGE & National & Both & $50+$ & 1267 \\
\hline
\end{tabular}

1920s was $167.4 \mathrm{~cm}$ according to Zenkevich and Almazova $^{9}$. Thus, the indicator of body height of men born in 1930 s might not have changed at all or changed very slightly compared to that of men born in the 1900s.
The obvious absence of the significant information for men born in the discussed period is the reason why we could not make a solid conclusion about a negative trend of body height. 
TABLE 4

SOURCES OF INFORMATION FOR CONTEMPORARY RUSSIA IN BATEN \& BLUM DATASET 21

\begin{tabular}{|c|c|}
\hline Birth decades & Full title of the article \\
\hline $\begin{array}{l}\text { 1810-1830; } \\
1870-1880 ; 1960\end{array}$ & $\begin{array}{l}\text { Mironov B. New Approaches to Old Problems: The Well-Being of the Population of Russia from } 1821 \text { to } 1910 \\
\text { as Measured by Physical Stature. }{ }^{25}\end{array}$ \\
\hline $1840-1860$ & $\begin{array}{l}\text { Erismann F. Studies on the physical development of factory workers in Central Russia (Untersuchungen über } \\
\text { die körperliche Entwicklung der Arbeiterbevölkerung in Zentralrussland). }{ }^{6} 6\end{array}$ \\
\hline 1890-1900 & Jarcho A. Die Altersveränderungen der Rassenmerkmale bei den Erwachsenen. ${ }^{22}$ \\
\hline $\begin{array}{l}1910 ; \\
1970-1980\end{array}$ & $\begin{array}{l}\text { Mironov B. Living Standards in Soviet Russia under Stalin: on the Data of the Stature of the Russian } \\
\text { Population. }{ }^{23}\end{array}$ \\
\hline $1920-1950$ & Mironov B. The Nutrition Standard of Life in the Soviet Russia under Stalin on the Anthropometric Data. ${ }^{24}$ \\
\hline $1990-2000$ & WHO/UNESCO \\
\hline
\end{tabular}

TABLE 5

SECULAR INCREASE IN HEIGHT DURING THE $20^{\mathrm{TH}}$ CENTURY FOR BIRTH DECADES ACCORDING TO TABLE 2 AND BATEN\&BLUM DATASET ${ }^{21}$, CM

\begin{tabular}{lcccc}
\hline & $1900-1930$ & $1930-1960$ & $1960-1980$ & Average for 1900-1980 \\
\hline Netherlands & 3.2 & 8.1 & 0.5 & 11.8 \\
Germany & 4.8 & 4.9 & 1.6 & 11.3 \\
United Kingdom of Great Britain and Northern Ireland & 4.5 & 3.0 & -0.1 & 7.5 \\
France & 3.1 & 5.0 & 1.6 & 9.7 \\
United States of America & 3.4 & 3.9 & 1.7 & 9.0 \\
European part of contemporary Russia & 1.2 & 7.5 & 1.5 & 10.2 \\
\hline
\end{tabular}

However, Baten and Blum ${ }^{21}$ dataset provides comparable information about other countries. This comparison of height changes in Russia with some European countries and USA led to the suggestion that political and socioeconomic transformations did have an adverse effect on pace of growth. Thus, the period of 1900-1930 for Germany, Netherlands, Great Britain, France and USA was characterized with rather significant secular changes in height (the increase equals from 3 to $5 \mathrm{~cm}$ ). On the territory of Russia the observed changes were $1.2 \mathrm{~cm}$.

At the same time, in most of the compared countries the increase in average male height either remained stable or slowed down during the period of 1930's-1960. However, for Russia 1930's-1960's it was the period of the most significant change in height (an increase up to $7.5 \mathrm{~cm}$, half of which occurred in the period 1930-1940's). This result varies greatly from the observations on 15-yearsold children population in Russian cities. Due to them the main increase in height occurred later, in 1960's-1980's $\mathrm{s}^{3,27}$. This tendency supports the idea of secular changes as a result of improving socioeconomic factors in the society.

In the 1960's-1980's the average indicator of male body height stabilized. Observed changes in the indicator were equaled approximately $1.5 \mathrm{~cm}$ in all considered countries. As a result, the total increase in male height on the discussed territory of Russia slightly differs from the value of average change in height in Netherlands and Germany in 1900-1980 (Table 5).

\section{Conclusions}

Secular changes during growth process were examined carefully due to separate and continuous measurements of children and adolescents in different cities or some regions of contemporary Russia, but never before it was done for adults and with the attempt to thoroughly describe comparable materials. The primary hypothesis is that political and socio-economic transformations affect male growth curve negatively was partly confirmed. We concluded that unfavorable political and socio-economic events (such as revolutions, World War I and World War II, purges and famines) influenced the pace of body height increase in men. While the main period of secular trend was fixed in the first decades of the 20th century in Germany, Netherlands and France, in considered territory of Russia it occurred later, in 1930-1960s. However, the total increase in male height was very similar for all mentioned territories (9-11 cm) in 1900-1980's. The question about the reasons of positive changes in stature is still open and should be the point of further discussions based on wide variety of social and economic statistical materials.

\section{Acknowledgements}

This paper was partly supported by the Moscow State University Grant for Leading Scientific Schools "Depos- 
itory of the Living Systems" in the framework of the MSU Development Program [EG]; Statistical analyses of data were conducted during the International Summer School "Child and Adolescent Growth and Nutrition" in Potsdam/Gülpe from the 1st to 7th of July in 2018. The Summer School was supported by the Auxological Society (Gesellschaft für Auxologie), and by the Society of Anthropology (Gesellschaft für Anthropologie). Dataset from Health Centers was provided by Central Scientific
Research Institute for Hygiene of the Russian Ministry of Health with the support of the Russian Science Foundation (grant No. 14-15-01085).

\section{Declaration of Interest}

The authors have no conflicts of interest relevant to this article to disclose.

\section{R E F E R E N C E S}

1. MIRONOV BN, The welfare of the population and the revolution in imperial Russia: XVII and early XX centuries (Ves Mir Publ, Moscow, 2012). - 2. TIMONIN AN, BURLYAEVA EA, NIKITIN NS, KLOCHKOVA SV, NIKITYUK DB, J Anat, 8 (2019) 9. - 3. GODINA E, YAMPOLSKAYA Y, Anthrop Kozl, 45 (2004) 51. — 4. LEHMANN A, IVANOVA E, GODINA E, SCHEFFLER C, Moscow University Anthropology Bulletin, 3 (2014) 55. - 5. GODINA EZ, KHOMYAKOVA IA, ZADOROZHNAYA LV, Archaeology, Ethnology \& Anthropology of Eurasia, 45 (2017) 146. - 6. TANNER JM, Growth as a mirror of the condition of society: secular trends and class distinctions. In: DEMIJIIAN A (Ed) Human Growth. A Multidisciplinary Review (Taylor \& Francis, London, 1986). - 7. BUNAK VV, Anthropological Journal, 1 (1932), 24. - 8. BUNAK VV, Origin and ethnic history of the Russian people (Nauka Publ., Moscow, 1965). - 9. ZENKEVICH PI, ALMAZOVA NY, On the change in the size of the body of the adult male population in the Central part of Soviet Union for the last 100 years. In: KURSHAKOVA YS, DUNAYEVSKAYA TN, ZENKEVICH PI (Eds): Problems of the size of anthropological standardization for the textile design (Moscow, 1978). - 10 . PURUNDZHAN AL, Geographic variability of anthropometric features in Soviet Union. In: KURSHAKOVA YS, DUNAYEVSKAYA TN, ZENKEVICH PI (Eds): Problems of the size of anthropological standardization for the textile design (Moscow, 1978). - 11. DERYABIN VY, PURUNDZHAN AL, On the geographical features of body composition in the Soviet Union (MSU Publ, Moscow, 1990). — 12. SEMASHKO INSTITUTE OF PUBLIC HYGIENE, Fizicheskoe razvitie detei i podrostkov gorodikh i sel'skikh mestnostei SSSR, Vypusk IV, Chast' II (Moscow 1988). - 13. STARUNOVA OA, RUDNEV SG, STARODUBOV VI, Rus. J. Num. Anal. Math. Model, 32 (2017) 315. — 14. Methods of morphophysiological research in anthropology (MSU Publ, Moscow, 1981). - 15. BOGIN B, VAREA C, HERMANUSSEN M, SCHEFFLER C, Am J Phys Anthropol., 165 (2018), 834. - 16. LEBEDEVA LS, Moscow University Geography Bulletin, 4 (2019) 24. - 17. HERMANUSSEN M. (ed.) Auxology - Studying Human Growth and Development (Schweizerbart Science Publishers, Stuttgart, 2013). - 18. LUMEY LH, STEIN AD, KAHN HS, VAN DER PAL-DE BRUIN KM, BLAUW GJ, ZYBERT PA, SUSSER ES, Int J Epidemiol, 36 (2007) 1196. - 19. HERMANUSSEN M, SCHEFFLER C, Anthropol. Anz. 73 (2016) 265. - 20. NCD RISK FACTOR COLLABORATION, eLife, 5 (2016). DOI: 10.7554/eLife.13410. - 21. BATEN J, BLUM M, Economic History of Developing Regions, 27:sup1 (2012) S66. DOI: 10.1080/20780389.2012.657489. — 22. JARCHO A, Anthropol. Anz., XII (1935). - 23. MIRONOV B, Living Standards in Soviet Russia under Stalin: on the Data of the Stature of the Russian Population. In: Proceedings (Conference Paper Presented at the 2nd International Conference on Economics and Human Biology, Munich, 2004). - 24. MIRONOV B, The Nutrition Standard of Life in the Soviet Russia under Stalin by the Anthropometric Data. In: The Economic History. A Yearbook (ROSSPEN, Moscow, 2004). — 25. MIRONOV B, Slavic Review, 58 (1999) 1. - 26. ERISMANN F, Archiv für soziale Gesetzgebung 1 (1888) 98. - 27. GODINA EZ, Anthropol. Anz, 68 (2011) 367.

\section{L.S. Lebedeva}

Public Opinion Foundation, Rochdelskaya St., 15/16 A, 123022, Moscow, Russia e-mail: lidiapakulova@gmail.com 


\section{SEKULARNE PROMJENE U VISINI MUŠKOG TIJELA U EUROPSKOM DIJELU RUSIJE TIJEKOM 20. STOLJEĆA}

\section{S A Ž E T A K}

Na prostoru suvremene Rusije u prvom dijelu 20. stoljeća dogodile su se značajne političke i ekonomske promjene. Naša je pretpostavka bila da su one negativno utjecale na krivulju rasta kod muškaraca. Za testiranje ove ideje, prikupljeni su podaci kako bi se izradio grafikon, koji ilustrira promjene u visini muškog tijela tijekom 20. stoljeća. Pretražili smo bibliografske izvore s podacima o tjelesnoj visini muškaraca i žena rođenih tijekom 20. stoljeća, s potpunim opisom mjerne metodologije, određivanja uzorka i značajnom geografskom raspodjelom podataka koji pokrivaju više od 15 teritorija zemlje - gradova ili regija. Takvi su kriteriji zadovoljeni su samo za muškarce. Pronašli smo samo 8 izvora koji bi se mogli smatrati pouzdanim u istraživanju. Dobiveni grafikon potvrđuje pozitivne promjene u visini muškog tijela na teritoriju europskog dijela suvremene Rusije: za one koji su rođeni 1900-ih to je bilo 166,1 cm, 1920-ih - 166,5 cm, 1940ih - $171 \mathrm{~cm}, 1960$-ih - 174,8 cm, a 1980-ih visina je dosegla 176,1 cm. U istraživanome razdoblju nisu utvrđene značajne negativne promjene ovog pokazatelja. Primarne hipoteze da političke i društveno-ekonomske transformacije negativno utječu na krivulju rasta muškaraca potvrđene su dijelom. Zaključili smo da nepovoljni politički i društveno-ekonomski događaji (poput revolucija, Prvog i Drugog svjetskog rata, čistki i gladi) utječu na tempo povećanja tjelesne visine kod muškaraca. Dok je glavno razdoblje sekularnog trenda bilo određeno u prvim desetljećima 20. stoljeća u Njemačkoj, Nizozemskoj i Francuskoj, na promatranom području Rusije nastupilo je kasnije, u 1930-1960-im. Međutim, ukupni porast muške visine bio je vrlo sličan za sva spomenuta područja $(9-11 \mathrm{~cm})$ u razdoblju od 1900-1980. 
